Published in final edited form as:

J Am Chem Soc. 2007 October 24; 129(42): 12780-12785. doi:10.1021/ja072944v.

\title{
Non-Carbohydrate Inhibitors of the Lectin DC-SIGN
}

\author{
M. Jack Borrok ${ }^{1}$ and Laura L. Kiessling ${ }^{1,2}$ \\ 1 Department of Biochemistry, University of Wisconsin, Madison, WI 53706 \\ 2Department of Chemistry, University of Wisconsin, Madison, WI 53706
}

\section{Abstract}

The C-type lectin dendritic cell-specific intracellular adhesion molecule 3-grabbing non-integrin (DC-SIGN), is found on the surface of dendritic cells. It can mediate adhesion between dendritic cells and $\mathrm{T}$ lymphocytes and facilitate antigen capture and presentation. Many pathogens can exploit DC-SIGN binding for nefarious purposes. For example, DC-SIGN can facilitate the dissemination of viruses, like HIV-1. Alternatively, some microbes (e.g., Mycobacterium tuberculosis) use their ability to interact with DC-SIGN to evade immune detection. The diverse roles attributed to DCSIGN provide impetus to identify ligands that can be used to explore its different functions. Such compounds also could serve as therapeutic leads. Most of the DC-SIGN ligands studied previously are mannose- or fucose-derived monosaccharides or oligosaccharides with inhibitory constants in the range of $0.1-10 \mathrm{mM}$. To identify monovalent ligands with more powerful DC-SIGN blocking properties, we devised a high-throughput fluorescence-based competition assay. This assay afforded potent non-carbohydrate, small molecule inhibitors $\left(\mathrm{IC}_{50}\right.$ values of 1.6-10 $\left.\mu \mathrm{M}\right)$. These compounds block not only DC-SIGN-carbohydrate interactions but also DC-SIGN-mediated cell adhesion. Thus, we anticipate that these non-carbohydrate inhibitors can be used to illuminate the role of DCSIGN in pathogenesis and immune function.

\section{Introduction}

Carbohydrate-protein interactions are crucial for physiological processes, including metabolism, cell-cell recognition, cell adhesion, fertilization, and differentiation. ${ }^{1-3}$ These interactions are also integral to many disease processes, such as tumor cell metastasis, inflammation, toxin binding, pathogen-cell interactions, and immune responses. ${ }^{1-3}$ Compounds that inhibit specific carbohydrate-protein binding events can serve as probes to study these interactions and as leads for the discovery of therapeutic agents.

Efforts to inhibit carbohydrate-binding proteins or lectins have focused on generating carbohydrate derivatives, but it is a challenge to convert carbohydrate leads into effective inhibitors. ${ }^{4-8}$ Because many lectins depend upon multivalent interactions ${ }^{9-14}$ typical monovalent carbohydrate ligands bind only weakly. Thus, to increase the potency of low affinity carbohydrate ligands can require the iterative synthesis and testing of many analogs. An appealing alternative to generating inhibitors of lectins is to start from a non-carbohydrate, small molecule ligand with higher affinity for its target.

Small molecules that effectively block carbohydrate-binding enzymes have been identified through high-throughput screening. ${ }^{5,7,15-20}$ Potent inhibitors of carbohydrate-modifying enzymes are known and can function as useful therapeutic agents (e.g., inhibitors of influenza virus neuraminidase) ${ }^{21-26}$ In contrast, there are few reports describing non-carbohydrate inhibitors of lectins. Most well-known examples are a result of intense efforts to generate compounds that block the selectins. ${ }^{4,27-33}$ No non-carbohydrate inhibitors of the intriguing lectin DC-SIGN had been described. 
DC-SIGN has been implicated in immunity. The lectin can function in cell adhesion, mediating interactions between dendritic cells and either neutrophils ${ }^{34-36}$ or T cells. ${ }^{37}$ Additionally, it has been suggested that DC-SIGN facilitates the migration of dendritic cells from the blood to the tissues. Specifically, the lectin can interact with the endothelial receptor intracellular adhesion molecule-2 (ICAM-2) to facilitate the rolling of dendritic cells along the endothelium, much like the selectins mediate leukocyte rolling. 38 Other experiments support a role for DCSIGN in the internalization of antigen for presentation to T cells. ${ }^{39-43}$

Given the roles of DC-SIGN in immune system function, it seems incongruous that pathogens can co-opt the lectin to cause disease. Specifically, DC-SIGN can promote the dissemination of a number of viruses (e.g., HIV, hepatitis C virus, human cytomegalovirus, Dengue virus, and Ebola virus). ${ }^{37,44-47}$ Moreover, DC-SIGN can participate in suppressing immune responses to some pathogens, (e.g., Mycobacterium tuberculosis and Heliobacter pylori). ${ }^{48-}$ 50 The detailed molecular mechanisms by which DC-SIGN engagement leads to these deleterious outcomes are unknown; unfortunately, the consequences can be dire. Thus, blocking DC-SIGN function could not only unravel its contribution to different biological processes but also have many therapeutic benefits. We therefore sought to identify small molecule inhibitors of DC-SIGN.

Efforts to identify inhibitors of DC-SIGN have followed the approaches used traditionally. Specifically, compounds based on mannose or mannose-containing oligosaccharides have been generated. Many of these exploit the advantages of multivalent binding by displaying the relevant sugar epitope on a peptidic or dendrimeric scaffold. 51,52 These multivalent inhibitors are 1-2 orders of magnitude more potent than their monovalent counterparts $\left(\mathrm{IC}_{50}\right.$ values of $50-100 \mu \mathrm{M})$. Given the modest affinities of even multivalent carbohydrate ligands for DCSIGN, we turned to non-carbohydrate inhibitors. To this end, we developed a high-throughput assay to screen large libraries of small molecules. This approach yielded effective noncarbohydrate ligands that inhibit DC-SIGN-carbohydrate interactions both in vitro and in a cell-based assay.

\section{Results and Discussion}

\section{High-Throughput Assay Development}

The design of high-throughput assays for lectins is complicated by their tendency to bind weakly to monovalent carbohydrate ligands. ${ }^{53}$ As mentioned, DC-SIGN is no exception; its affinity for monosaccharide ligands is weak $\left(\mathrm{K}_{\mathrm{i}}=8.7 \mathrm{mM}\right.$ for $\mathrm{N}$-acetyl mannosamine, $6.7 \mathrm{mM}$ for $\mathrm{L}$-fucose) and for oligosaccharides is modest $\left(\mathrm{K}_{\mathrm{i}}=0.21 \mathrm{mM}\right.$ for Man $\left.\mathrm{GlcNAc}_{2}\right){ }^{54}$ To develop a high-throughput competition assay, we wanted to maximize the apparent affinity of the DC-SIGN-ligand interaction. In this way, we could minimize reagent use and sensitively detect DC-SIGN binding. To this end, we employed both a multivalent target as well as a multivalent probe in our assay.

DC-SIGN-carbohydrate interactions have been assessed previously using a medium throughput assay that employs a radiolabelled carbohydrate derivative. ${ }^{54}$ Specifically, a multivalent ${ }^{135}$ I-labeled mannose 30 -BSA conjugate was used to measure binding of carbohydrate ligands to either the immobilized carbohydrate recognition domain (CRD) or extracellular domain (ECD) of DC-SIGN. Though sensitive, the use of radioactivity is a drawback. Thus, we sought to detect protein-carbohydrate interactions using fluorescence. Guided by the previous approach, we envisioned monitoring the ability of a compound to compete with a fluorescent mannose derivative for an immobilized form of DC-SIGN. The requisite fluorescent glycoconjugate could be synthesized from the reaction of commercially available fluorescein isothiocyanate with mannosylated bovine serum albumin (1-3 copies of fluorescein/BSA). Mannosylated BSA (20-25 copies of Man/BSA) was assembled by 
treatment of the protein with $\alpha$-D-mannopyranosyl phenyl isothiocyanate. The resulting glycoconjugate (Man-Fl-BSA) serves as a ligand for immobilized oligomeric DC-SIGN. We employed the tetrameric form of DC-SIGN (i.e., the entire extracellular domain consisting of the carbohydrate recognition domain or CRD and oligomerization or neck region). ${ }^{55}$ The tetrameric, but not monomeric, form of DC-SIGN afforded reproducible results.

With this assay design, we tested whether the interactions between immobilized DC-SIGN and Man-Fl-BSA depend upon protein-carbohydrate complexation. Because DC-SIGN is a C-type lectin, its ability to interact with the fluorescent glycoconjugate probe should depend on the presence of $\mathrm{Ca}^{2+}$. When the $\mathrm{Ca}^{2+}$ chelator EDTA $(10 \mathrm{mM})$ was added, the DC-SIGNfluorescent glycoconjugate interaction was blocked completely. Likewise, fluorescent probe binding was inhibited by mannose derivatives including unlabeled $\operatorname{Man}_{20-25} \mathrm{BSA}$ and mannan $(1 \mathrm{mg} / \mathrm{ml})$.

The fluorescent mannosylated BSA and the immobilized tetrameric DC-SIGN are both multivalent. One potential concern with an assay based upon high valency interactions is that it would not be sensitive enough to detect inhibition by monovalent compounds. To address this issue, we assessed the activity of monosaccharides known to have $K_{i}$ values in the range of $10^{-3} \mathrm{M}$. With their low affinity, these ligands provide a measure of assay sensitivity. The resulting $\mathrm{IC}_{50}$ values, $6.9 \pm 3.2 \mathrm{mM}$ for $\mathrm{N}$-acetyl mannosamine (ManNAc) and $6.0 \pm 3.0 \mathrm{mM}$ for L-fucose, are within error of reported $K_{i}$ values. ${ }^{54}$ These results indicate that our assay has the requisite sensitivity—it can be used to identify even modest inhibitors (Figure 1a).

\section{Identifying inhibitors of DC-SIGN-carbohydrate interactions}

The fluorescence assay was adapted to a 384-well microtiter plate format, thereby allowing its implementation in high-throughput screening. We tested two commercially available small molecule libraries: the 16,000-member Chembridge DIVERSet and 20,000-member library from Chemical Diversity Labs (ChemDiv). In the initial screens, each compound was tested a final concentration of $100 \mu \mathrm{M}$. As benchmarks for comparison, each plate included 3 controls: DMSO alone, EDTA $(10 \mathrm{mM})$, and $\mathrm{N}$-acetyl mannosamine $(50 \mathrm{mM})$. Compounds that led to samples with fluorescence intensities three times below the standard deviation of the DMSO control were termed hits. Approximately $0.6 \%$ of compounds met this criterion. These initial hits were then evaluated at a lower concentration $(33 \mu \mathrm{M})$. The mean $Z$ '-factor ${ }^{56}$ of our assay (a measure of the robustness of a high throughput screen) was 0.76 . This value was calculated using data from EDTA and DMSO control wells in the ChemDiv screening plates. Our Z'factor (between 0.5 and 1) is indicative of an excellent assay with ample separation between positive and negative control samples. From this analysis, we identified several noncarbohydrate compounds that exhibited consistent inhibition, and these were further characterized.

The $\mathrm{IC}_{50}$ values of active compounds range from 1.6 to $32 \mu \mathrm{M}$ (Figure $1 \mathrm{~b}$ and Figure 2). Thus, compared to DC-SIGN-binding monosaccharides, the non-carbohydrate, small molecule inhibitors identified are approximately 1000 -fold more potent. The excellent activities of these compounds also compare favorably with the $K_{\mathrm{i}}$ of $210 \mu \mathrm{M}$ for the oligosaccharide $\mathrm{Man}_{9} \mathrm{GlcNAc}_{2} .{ }^{54}$ Thus, the DC-SIGN inhibitors identified are intriguing leads.

Key physiological roles for DC-SIGN include facilitating dendritic cell adhesion to viruses, bacteria, and immune system cells. Thus, we assessed the abilities of the active small molecules to block DC-SIGN-mediated cell adhesion. In contrast to mock-transfected 293FT cells, cells transiently transfected with a plasmid encoding DC-SIGN adhere to mannan-coated plates. Cell binding was abolished upon the addition of EDTA, which indicates that cell adhesion to the immobilized oligosaccharide is $\mathrm{Ca}^{2+}$-dependent. In addition, carbohydrates known to interact with DC-SIGN (L-fucose and $\mathrm{N}$-acetyl mannosamine) also blocked cell adhesion 
(Figure 3a). When the active small molecules from the high-throughput screen were tested, they inhibited the adhesion of DC-SIGN-transfected cells effectively.

The $\mathrm{IC}_{50}$ values of the small molecules in the cell adhesion assay range from $7.3 \mu \mathrm{M}$ to 227 $\mu \mathrm{M}$ (Figure $3 \mathrm{~b}$ and Table 1). These values are higher (ca. 10-fold) than those determined in the fluorescence binding assay. Similarly, the monosaccharide $\mathrm{N}$-acetyl mannosamine was less potent (4-fold) in the cell adhesion assay. Several factors might account for the apparent decreased potency of the inhibitors in the cell adhesion assay. For instance, if DC-SIGN binds mannan more tightly than Man-Fl-BSA, it will be more difficult to block the former interaction. Alternatively, the number of DC-SIGN-ligand interactions might vary between the assays, which would influence the avidity of binding. Whatever the source of the difference, it is notable that the compounds identified in the fluorescence screen inhibit DC-SIGN-specific cell adhesion at concentrations approximately 100 times lower than those required for $\mathrm{N}$-acetyl mannosamine.

The DC-SIGN inhibitors we have identified bear no resemblance to the known carbohydrate ligands (Figure 2). Indeed, there is a paucity of hydroxyl or carboxyl groups in the active compounds; therefore, they are lacking functional groups that could chelate $\mathrm{Ca}^{2+}$ in a manner similar to that employed by the carbohydrate ligands. 57,58 The attributes of the DC-SIGN ligands therefore differ from those of the selectin ligands. The latter possess either hydroxyl or carboxylic acid groups. ${ }^{4,27-33}$ Still, many of the DC-SIGN ligands we identified possess amide carbonyl groups, which could interact with a protein-bound $\mathrm{Ca}^{2+}$ ion. Clearly, carbohydrate-like features are not required for effective DC-SIGN inhibition.

The simplest interpretation of our results is that the non-carbohydrate small molecules can bind in a site similar to the occupired by the carbohydrate ligands. Still, we cannot rule out the possibility that the non-carbohydrate ligands identified bind to DC-SIGN at a site that is different than that used by oligosaccharide ligands. It is intriguing that the small molecules identified possess aromatic groups because aromatic side chains often line carbohydrate binding sites ${ }^{10,59,60}$ Moreover, adding an aromatic substituent to an oligosaccharide ligand can result in a derivative exhibiting enhanced binding to its lectin target. ${ }^{7,61-64}$ Another feature shared by the carbohydrate and non-carbohydrate inhibitors of DC-SIGN is their ability to occupy an extended binding site. DC-SIGN binds carbohydrate ligands in a shallow but extended groove (Figure 4) and the small molecules identified also could interact with such a groove. Accordingly, structural studies to elucidate the mode by which these small molecules complex to DC-SIGN would be illuminating.

Of the seven compounds identified, six (1-3 and $\mathbf{5}$ and $\mathbf{6}$ ) belong to two structural classes (Figure 2). These different classes can serve as templates for the generation of new compounds with improved activities or alternative properties. Specifically, modifications of the active ligands can be explored to yield more potent monovalent ligands. Alternatively, fluorophores can be introduced to examine DC-SIGN localization and internalization. Finally, the activity of the non-carbohydrate ligands can also be enhanced through their conversion into multivalent ligands. Multivalent display could also improve the specificity of these inhibitors for DC-SIGN over other mannose-binding C-type lectins, because scaffolds could be made to match the specific oligomerization state (tetramer) of DC-SIGN. 65

Our identification of small molecule ligands for DC-SIGN was facilitated by the generation of a simple, yet effective, high-throughput assay. The reagents required for implementing this assay are readily accessible. Fluorescent glycoconjugates with different lectin specificities can be assembled using a similar strategy. Specifically, BSA conjugates displaying carbohydrates and fluorophores can be generated from different sugars and fluorophores; the ratio of these can be altered to tailor the glycoconjugate for binding to C-type lectins with differing 
specificities. ${ }^{66}$ Thus, we anticipate that similar high-throughput assays can easily be implemented to yield ligands for other medically or physiologically important lectins.

Although low-affinity protein-carbohydrate interactions are ubiquitous and physiologically important, they seldom are the targets of small molecule inhibition. Lectins typically possess shallow and solvent exposed carbohydrate binding sites, which can be difficult to block effectively, The non-carbohydrate selectin ligands identified recently are rare examples of potent lectin inhibitors. $26-28,67,68$ Our results provide additional evidence that highly effective non-carbohydrate inhibitors for physiologically important lectins can be found. We anticipate that the compounds we have identified can be used to illuminate the function of DCSIGN.

\section{Experimental Procedures}

\section{Production of Soluble DC-SIGN}

A plasmid encoding the DC-SIGN extracellular domain (ECD) was provided by Dr. Kurt Drickamer (University of Oxford). ${ }^{54}$ Briefly, the plasmid was transformed into Escherichia coli strain BL21/DE3, and the resulting cells were stored in $10 \%$ glycerol at $-70{ }^{\circ} \mathrm{C}$. This glycerol stock was used to inoculate a flask containing $50 \mathrm{~mL}$ Luria-Bertani (LB) media supplemented with ampicillin $(100 \mu \mathrm{g} / \mathrm{mL})$, and the culture was grown overnight at $37^{\circ} \mathrm{C}$. This culture was then used to inoculate 4 liters of LB media ( $100 \mu \mathrm{g} / \mathrm{ml}$ ampicillin), and cells were allowed to grow at $37{ }^{\circ} \mathrm{C}$ until an $\mathrm{OD}_{600}$ of 0.7 was reached. Gene expression was then induced with $100 \mathrm{mg} /$ liter isopropyl- $\beta$-р-thiogalactoside, and the culture was incubated at 37 ${ }^{\circ} \mathrm{C}$ with shaking for 3 additional hours. Bacteria were harvested by centrifugation at $8,000 \times$ $\mathrm{g}$ for 10 minutes. Cell pellets were washed with $10 \mathrm{~m}$ Tris- $\mathrm{HCl}, \mathrm{pH} 7.8$ and again centrifuged at $8,000 \times \mathrm{g}$ for 10 minutes at $4{ }^{\circ} \mathrm{C}$. Cells were resuspended in $10 \mathrm{~m}_{\mathrm{M}}$ Tris-HCl, $\mathrm{pH} 7.8$ and sonicated for approximately 2 minutes. Inclusion bodies were isolated by centrifugation at $10,000 \times \mathrm{g}$ for $10 \mathrm{~min}$ at $4{ }^{\circ} \mathrm{C}$. This pellet was solubilized in $4 \mathrm{~m}$ guanidine- $\mathrm{HCl}$ containing 10 $\mathrm{m}_{\mathrm{M}}$ Tris- $\mathrm{HCl}(20 \mathrm{~mL})$ and $0.01 \% \beta$-mercaptoethanol at $\mathrm{pH} 7.8$. This mixture was sonicated briefly and then centrifuged at $137,000 \times \mathrm{g}$ for $30 \mathrm{~min}$ at $4{ }^{\circ} \mathrm{C}$. The supernatant was diluted with 3 volumes of high salt loading buffer (HSLB; $25 \mathrm{mM}$ Tris-HCl, $1 \mathrm{M} \mathrm{NaCl}, 5 \mathrm{mM}$ $\mathrm{CaCl}_{2}, \mathrm{pH}$ 7.8) and dialyzed overnight against HSLB to initiate protein refolding. After dialysis, the insoluble precipitate was removed by centrifugation at $142,000 \times \mathrm{g}$ for $1 \mathrm{~h}$ at $4{ }^{\circ}$ C. This soluble fraction was then further purified over a mannose-substituted Sepharose column. Protein was loaded onto the column and washed with 4-5 column volumes of HSLB. The ECD of DC-SIGN was eluted with $1 \mathrm{M} \mathrm{NaCl}, 25 \mathrm{~mm}$ Tris-HCl, $5 \mathrm{~mm}$ ethylenediaminetetraacetic acid (EDTA) at $\mathrm{pH}$ 7.8. Purified protein was then dialyzed into low salt loading buffer (LSLB; $25 \mathrm{mM}$ Tris-HCl, $125 \mathrm{mM} \mathrm{NaCl}, 5 \mathrm{mM} \mathrm{CaCl}_{2}, \mathrm{pH} 7.8$ ) and concentrated with a Centriplus centrifugal filter device (Amicon)

\section{Competition Assay using Bovine Serum Albumin Modified with a-D-Mannopyranosyl Phenyl Isothiocyanate and Fluorescein Isothiocyanate (Man-FI-BSA)}

The ECD from DC-SIGN was immobilized onto black Polysorb 384-well plates (Nunc) by overnight incubation at $4{ }^{\circ} \mathrm{C}(25 \mu \mathrm{l} / \mathrm{well}, 200 \mu \mathrm{g} / \mathrm{ml})$. Plates were washed with LSLB and then blocked with $2 \%$ BSA in LSLB $(50 \mu 1 /$ well) for 2 hours. Plates were washed once more with LSLB and then incubated with $20 \alpha \mathrm{l} \mathrm{Man-Fl-BSA} \mathrm{(Sigma;} 20 \mu \mathrm{g} / \mathrm{ml}$ ) probe in $2 \%$ BSA-LSLB and compound ( $1 \mu \mathrm{L}$ of DMSO solution). After 1 hour, plates were washed 3 times with LSLB and the fluorescence emission was determined using a Wallac Envision plate reader (Perkin Elmer) at an excitation wavelength of $480 \mathrm{~nm}$ and an emission wavelength of $520 \mathrm{~nm}$. 


\section{Plasmids, Antibodies, and Cell Lines}

Plasmid pcDNA3-DC-SIGN ${ }^{69}$ (NIH AIDS Research and Reference Reagent Program) was transiently transfected into 293FT cells (Invitrogen) with Lipofectamine 2000 reagent (Invitrogen). Cells were treated with DMEM growth media with 10\% FBS supplemented with non-essential amino acids $(0.1 \mathrm{mM})$, sodium pyruvate $(1 \mathrm{mM})$, L-glutamate $(1 \mathrm{mM})$ and 500 $\mu \mathrm{g} / \mathrm{ml} \mathrm{Geneticin} \mathrm{(Invitrogen).} \mathrm{Expression} \mathrm{of} \mathrm{DC-SIGN} \mathrm{was} \mathrm{confirmed} \mathrm{by} \mathrm{western} \mathrm{blot} \mathrm{using}$ a DC-SIGN monoclonal antibody (DC4) ${ }^{69,70}$ that recognizes the neck region of DC-SIGN (NIH AIDS Research and Reference Reagent Program).

\section{DC-SIGN Mediated Cell Adhesion Assay}

Flat-Bottom Polysorp 96-well plates (Nunc) were incubated overnight with $1 \mathrm{mg} / \mathrm{ml}$ mannan from Saccharomyces cerevisiae (Sigma). Plates were then blocked with $1 \%$ BSA in PBS for 2 hours. Cells were labeled with BCECF-AM (Invitrogen) for 20 minutes in PBS at room temperature. Cells were then loaded onto plates (40,000 per well). DMSO or inhibitors were then added ( $1 \mu 1$ of a DMSO solution of the compound was added to $50 \mu 1$ cell suspension), and the cells were incubated for 1 hour at $37^{\circ} \mathrm{C}$. The plate was gently agitated and wells were washed (2x) with PBS. Cells were treated with lysis buffer ( $25 \mathrm{mM}$ Tris, $\mathrm{pH} 8.4$ and $0.1 \%$ SDS), and fluorescence was quantified with a Wallac Envision plate reader (Perkin Elmer). DC-SIGN-specific adhesion was calculated by subtracting the adhesion of mock-infected cells plus DMSO or inhibitors from the adhesion of cells transfected with a vector encoding DCSIGN plus DMSO (control) or inhibitor. Percent DC-SIGN-specific adhesion was calculated by normalizing the adhesion of transfected cells treated with DMSO alone to $100 \%$.

\section{Supplementary Material}

Refer to Web version on PubMed Central for supplementary material.

\section{Acknowledgments}

This research was supported by the National Institutes of Health (R01 GM049975). We thank Prof. K. Drickamer for supplying the DC-SIGN expression vector. The following reagents were obtained through the National Institutes of Health AIDS Research Reference and Reagent Program, Division of AIDS, NIAID, NIH: DC-SIGN monoclonal antibody (DC4) from Drs. F. Baibaud, S. Pöhlmann, J.A. Hoxie, and R.W. Doms; pcDNA3-DC-SIGN from Drs. F. Baibaud, S. Pöhlmann, J.A. Hoxie, F. Kirchoff, E. Soilleux, and R.W. Doms. We thank N. R. Peters and M. K. Fitzgerald (Keck University of Wisconsin Comprehensive Cancer Center Small Molecule Screening Facility) for screening assistance, K. Alfare for helpful conversations, and P.D. Friesen for use of equipment. M.J.B. was supported by an NIH Molecular Biosciences Training Grant (T32 GM07215) and a Steenbock Fellowship from the UWMadison Department of Biochemistry.

\section{References}

1. Varki A. Glycobiology 1993;3:97-130. [PubMed: 8490246]

2. Bertozzi CR, Kiessling LL. Science 2001;291:2357-2364. [PubMed: 11269316]

3. Werz DB, Seeberger PH. Chem. Eur. J 2005;11:3194-3206.

4. Simanek EE, McGarvey GJ, Jablonowski JA, Wong CH. Chem. Rev 1998;98:833-862. [PubMed: 11848916]

5. Compain P, Martin OR. Bioorg. Med. Chem 2001;9:3077-3092. [PubMed: 11711283]

6. Kaila N, Thomas BE. Med. Res. Rev 2002;22:566-601. [PubMed: 12369089]

7. Pieters RJ. Chembiochem 2006;7:721-728. [PubMed: 16566049]

8. Schuster MC, Mann DA, Buchholz TJ, Johnson KM, Thomas WD, Kiessling LL. Org. Lett 2003;5:1407-1410. [PubMed: 12713285]

9. Mammen M, Choi SK, Whitesides GM. Angew. Chem. Int. Ed 1998;37:2755-2794.

10. Kiessling LL, Pohl NL. Chem. Biol 1996;3:71-77. [PubMed: 8807830] 
11. Weis WI, Drickamer K. Annu. Rev. Biochem 1996;65:441-473. [PubMed: 8811186]

12. Drickamer K, Taylor ME. Annu. Rev. Cell Biol 1993;9:237-264. [PubMed: 8280461]

13. Brewer CF, Miceli MC, Baum LG. Curr. Opin. Struct. Biol 2002;12:616-623. [PubMed: 12464313]

14. Collins BE, Paulson JC. Curr. Opin. Chem. Biol 2004;8:617-625. [PubMed: 15556405]

15. Carlson EE, May JF, Kiessling LL. Chem. Biol 2006;13:825-837. [PubMed: 16931332]

16. Soltero-Higgin M, Carlson EE, Phillips JH, Kiessling LL. J. Am. Chem. Soc 2004;126:10532-10533. [PubMed: 15327298]

17. Hu Y, Heim JS, Chen L, Ginsberg C, Gross B, Kraybill B, Tiyanont K, Fang X, Wu T, Walker S. Chem. Biol 2004;11:703-711. [PubMed: 15157881]

18. Helm JS, Hu YN, Chen L, Gross B, Walker S. J. Am. Chem. Soc 2003;125:11168-11169. [PubMed: 16220917]

19. Sim MM, Ng SB, Buss AD, Crasta SC, Goh KL, Lee SK. Bioorg. Med. Chem. Lett 2002;12:697699. [PubMed: 11844704]

20. Ma YF, Stern RJ, Scherman MS, Vissa VD, Yan WX, Jones VC, Zhang FQ, Franzblau SG, Lewis WH, McNeil MR. Antimicrob. Agents Chemother 2001;45:1407-1416. [PubMed: 11302803]

21. De Clercq E. Nat. Rev. Drug Disc 2006;5:1015-1025.

22. Vonitzstein M, et al. Nature 1993;363:418-423. [PubMed: 8502295]

23. Kim CU, Lew W, Williams MA, Liu H, Zhang L, Swaminathan S, Bischofberger N, Chen MS, Mendel DB, Tai CY, Laver WG, Stevens RC. J. Am. Chem. Soc 1997;119:681-690. [PubMed: 16526129]

24. Lillelund VH, Jensen HH, Liang XF, Bols M. Chem. Rev 2002;102:515-553. [PubMed: 11841253]

25. Ganem B. Acc. Chem. Res 1996;29:340-347.

26. Asano N, Nash RJ, Molyneux RJ, Fleet GWJ. Tet. Asymmetry 2000;11:1645-1680.

27. Kaila N, Janz K, DeBernardo S, Bedard PW, Camphausen RT, Tam S, Tsao DHH, Keith JC, Nickerson-Nutter C, Shilling A, Young-Sciame R, Wang Q. J. Med. Chem 2007;50:21-39. [PubMed: 17201408]

28. Kaila N, Janz K, Huang A, Moretto A, DeBernardo S, Bedard PW, Tam S, Clerin V, Keith JC, Tsao DHH, Sushkova N, Shaw GD, Camphausen RT, Schaub RG, Wang Q. J. Med. Chem 2007;50:4064. [PubMed: 17201409]

29. Ohta S, Inujima Y, Abe M, Uosaki Y, Sato S, Miki I. Inflammation Res 2001;50:544-551.

30. Ulbrich HK, Luxenburger A, Prech P, Eriksson EE, Soehnlein O, Rotzius P, Lindbom L, Dannhardt G. J. Med. Chemistry 2006;49:5988-5999.

31. Kaila N, et al. J. Med. Chem 2005;48:4346-4357. [PubMed: 15974587]

32. Kerr KM, Auger WR, Marsh JJ, Comito RM, Fedullo RL, Smits GJ, Kapelanski DP, Fedullo PF, Channick RN, Jamieson SW, Moser KM. Am. J. Respir. Crit. Care Med 2000;162:14-20. [PubMed: 10903213]

33. Kogan TP, Dupre B, Bui H, McAbee KL, Kassir JM, Scott IL, Hu X, Vanderslice P, Beck PJ, Dixon RAF. J. Med. Chem 1998;41:1099-1111. [PubMed: 9544210]

34. van Gisbergen K, Geijtenbeek TBH, van Kooyk Y. Trends Immunol 2005;26:626-631. [PubMed: 16182604]

35. van Gisbergen K, Ludwig IS, Geijtenbeek TBH, van Kooyk Y. FEBS Lett 2005;579:6159-6168. [PubMed: 16246332]

36. van Gisbergen K, Sanchez-Hernandez M, Geijtenbeek TBH, van Kooyk Y. J. Exp. Med 2005;201:1281-1292. [PubMed: 15837813]

37. Geijtenbeek TBH, Kwon DS, Torensma R, van Vliet SJ, van Duijnhoven GCF, Middel J, Cornelissen ILMHA, Nottet HSLM, KewalRamani VN, Littman DR. Cell 2000;100:587-597. [PubMed: 10721995]

38. Geijtenbeek TBH, Krooshoop D, Bleijs DA, van Vliet SJ, van Duijnhoven GCF, Grabovsky V, Alon R, Figdor CG, van Kooyk Y. Nat. Immunol 2000;1:353-357. [PubMed: 11017109]

39. Geijtenbeek TBH, van Vliet SJ, Engering A, t Hart BA, van Kooyk Y. Annu. Rev. Immunol 2004;22:33-54. [PubMed: 15032573] 
40. Engering A, Geijtenbeek TBH, van Vliet SJ, Wijers M, van Liempt E, Demaurex N, Lanzavecchia A, Fransen J, Figdor CG, Piguet V, van Kooyk Y. J Immunol 2002;168:2118-2126. [PubMed: 11859097]

41. Dakappagari N, Maruyama T, Renshaw M, Tacken P, Figdor C, Torensma R, Wild MA, Wu DY, Bowdish K, Kretz-Rommel A. J. Immunol 2006;176:426-440. [PubMed: 16365436]

42. Lam JS, Mansour MK, Specht CA, Levitz SM. J. Immunol 2005;175:7496-7503. [PubMed: 16301657]

43. Tacken PJ, de Vries IJM, Gijzen K, Joosten B, Wu DY, Rother RP, Faas SJ, Punt CJA, Torensma R, Adema GJ, Figdor CG. Blood 2005;106:1278-1285. [PubMed: 15878980]

44. van Kooyk Y, Geijtenbeek TBH. Nat. Rev. Immunol 2003;3:697-709. [PubMed: 12949494]

45. Alvarez CP, Lasala F, Carrillo J, Muniz O, Corbi AL, Delgado R. J. Virol 2002;76:6841-6844. [PubMed: 12050398]

46. Tassaneetrithep B, Burgess TH, Granelli-Piperno A, Trumpfherer C, Finke J, Sun W, Eller MA, Pattanapanyasat K, Sarasombath S, Birx DL, Steinman RM, Schlesinger S, Marovich MA. J. Exp. Med 2003;197:823-829. [PubMed: 12682107]

47. Wu L, KewalRamani VN. Nat. Rev. Immunol 2006;6:859-868. [PubMed: 17063186]

48. Geijtenbeek TBH, van Vliet SJ, Koppel EA, Sanchez-Hernandez M, Vandenbroucke-Grauls C, Appelmelk B, van Kooyk Y. J. Exp. Med 2003;197:7-17. [PubMed: 12515809]

49. Tailleux L, Schwartz O, Herrmann JL, Pivert E, Jackson M, Amara A, Legres L, Dreher D, Nicod LP, Gluckman JC, Lagrange PH, Gicquel B, Neyrolles O. J. Exp. Med 2003;197:121-127. [PubMed: 12515819]

50. Bergman MP, Engering A, Smits HH, van Vliet SJ, van Bodegraven AA, Wirth HP, Kapsenberg ML, Vandenbroucke-Grauls C, van Kooyk Y, Appelmelk BJ. J. Exp. Med 2004;200:979-990. [PubMed: 15492123]

51. Frison N, Taylor ME, Soilleux E, Bousser M-T, Mayer R, Monsigny M, Drickamer K, Roche A-C. J. Biol. Chem 2003;278:23922-23929. [PubMed: 12695508]

52. Tabarani G, Reina JJ, Ebel C, Vives C, Lortat-Jacob H, Rojo J, Fieschi F. FEBS Letters 2006;580:2402-2408. [PubMed: 16616922]

53. Mann, DA.; Kiessling, LL. Glycochemistry: Principles, Synthesis, and Application. Wang, PG.; Bertozzi, CR., editors. New York: Marcel Dekker; 2001. p. 221-277.

54. Mitchell DA, Fadden AJ, Drickamer K. J. Biol. Chem 2001;276:28939-28945. [PubMed: 11384997]

55. Feinberg H, Guo Y, Mitchell DA, Drickamer K, Weis WI. J. Biol. Chem 2005;280:1327-1335. [PubMed: 15509576]

56. Zhang J-H, Chung TDY, Oldenburg KR. J. Biomol. Screen 1999;4:67-73. [PubMed: 10838414]

57. Guo Y, Feinberg H, Conroy E, Mitchell DA, Alvarez R, Blixt O, Taylor ME, Weis WI, Drickamer K. Nat. Struct.Mol. Biol 2004;11:591-598. [PubMed: 15195147]

58. Feinberg H, Mitchell DA, Drickamer K, Weis WI. Science 2001;294:2163-2166. [PubMed: 11739956]

59. Quiocho FA. Annu. Rev. Biochem 1986;55:287-315. [PubMed: 3527044]

60. Jimenez-Barbero J, Asensio JL, Canada FJ, Poveda A. Curr. Opin. Struct. Biol 1999;9:549-555. [PubMed: 10508763]

61. Bernardi A, Arosio D, Potenza D, Sanchez-Medina I, Mari S, Canada FJ, Jimenez-Barbero J. Chem. Eur. J 2004;10:4395-4406.

62. Poretz RD, Goldstein IJ. Biochem. Pharm 1971;20:2727-\&. [PubMed: 5114508]

63. Page D, Zanini D, Roy R. Bioorg. Med. Chem 1996;4:1949-1961. [PubMed: 9007279]

64. Sorme P, Qian YN, Nyholm PG, Leffler H, Nilsson UJ. Chembiochem 2002;3:183-189. [PubMed: 11921396]

65. Gestwicki JE, Cairo CW, Strong LE, Oetjen KA, Kiessling LL. J. Am. Chem. Soc 2002;124:1492214933. [PubMed: 12475334]

66. Monsigny M, Roche AC, Midoux P. Biol. Cell 1984;51:187-196. [PubMed: 6240301]

67. Slee DH, Romano SJ, Yu JH, Nguyen TN, John JK, Raheja NK, Axe FU, Jones TK, Ripka WC. J. Med. Chem 2001;44:2094-2107. [PubMed: 11405647] 
68. Schon MP, Krahn T, Schon M, Rodriguez ML, Antonicek H, Schultz JE, Ludwig RJ, Zollner TM, Bischoff E, Bremm KD, Schramm M, Henninger K, Kaufmann R, Gollnick HPM, Parker CM, Boehncke WH. Nat. Med 2002;8:366-372. [PubMed: 11927942]

69. Pohlmann S, Baribaud F, Lee B, Leslie GJ, Sanchez MD, Hiebenthal-Millow K, Munch J, Kirchhoff F, Doms RW. J.Virol 2001;75:4664-4672. [PubMed: 11312337]

70. Soilleux EJ, Barten R, Trowsdale J. J. Immunol 2000;165:2937-2942. [PubMed: 10975799] 
(a)

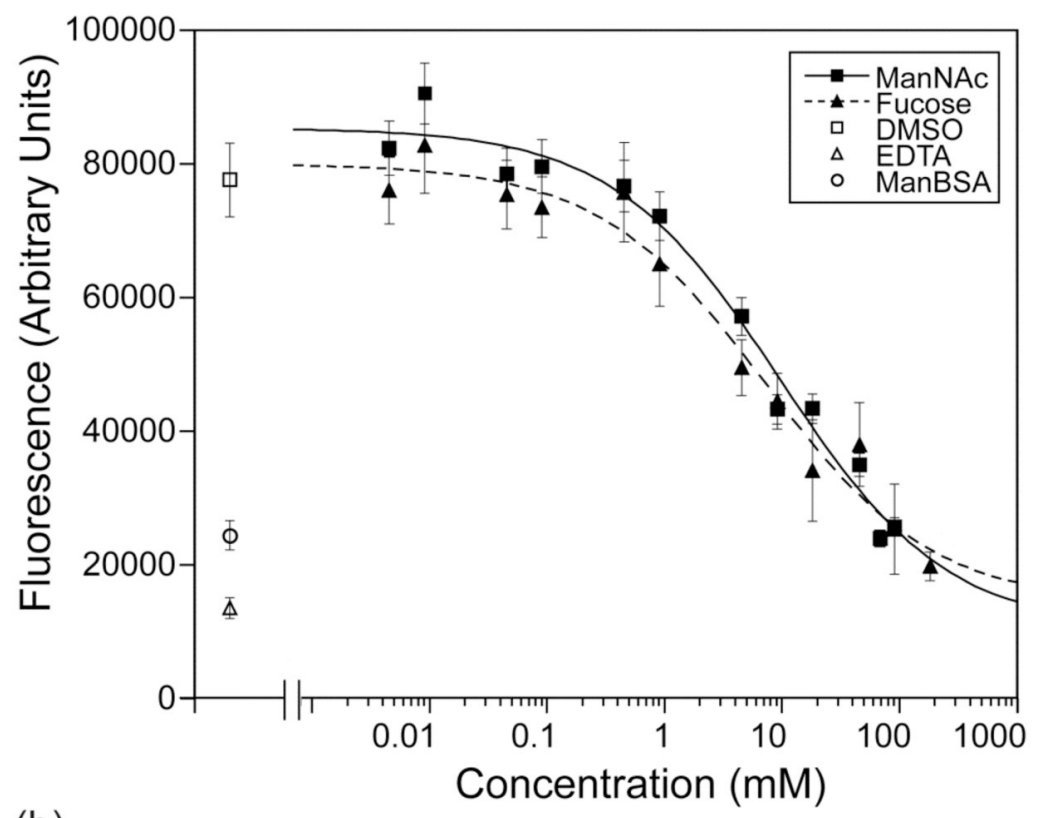

(b)

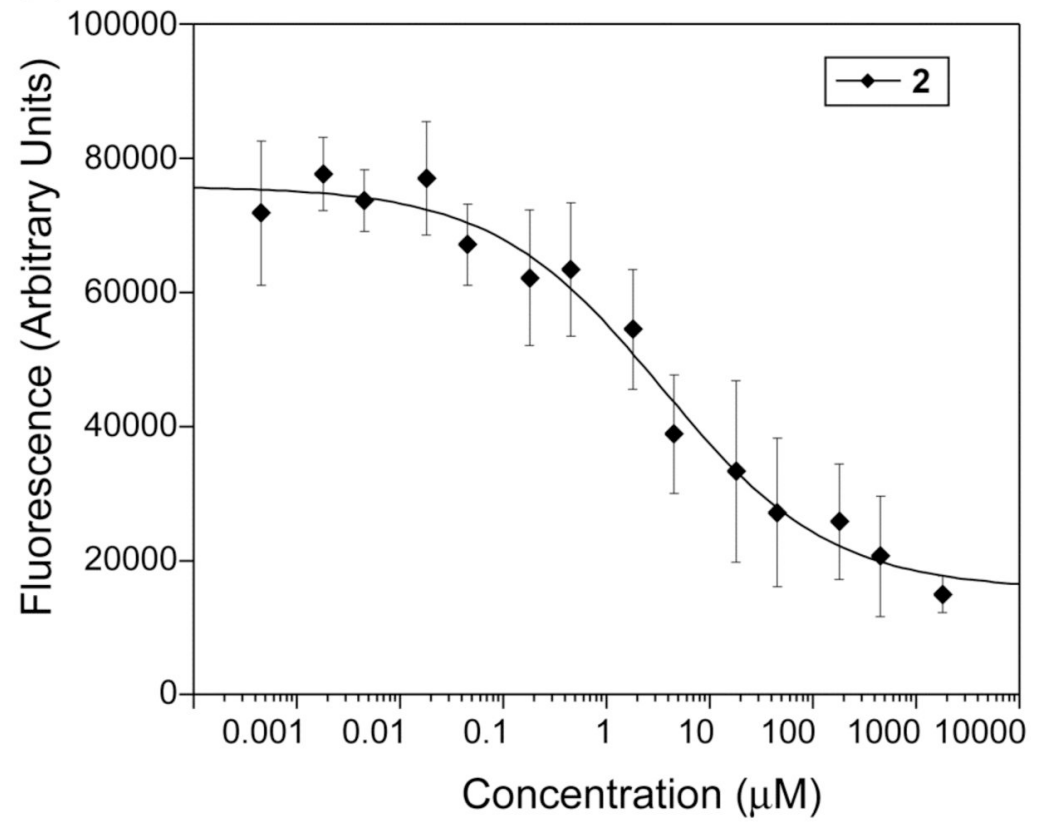

Figure 1.

Binding curves generated in the competition assay using Man-Fl-BSA. (a) N-Acetyl mannosamine (ManNAc) and $\mathrm{L}$-fucose inhibit binding of Man-Fl-BSA probe to immobilized DC-SIGN. DMSO alone did not affect probe binding, whereas EDTA $(10 \mathrm{mM})$, and unlabeled mannose $20-25$-BSA $(50 \mu \mathrm{g} / \mathrm{ml})$ blocked probe binding completely. (b) Compound 2 potently inhibits probe binding to immobilized DC-SIGN. 
<smiles>O=C1Nc2cc(C(=O)N3CCN(c4ccccc4)CC3)ccc2NC1CSCc1c(F)cccc1Cl</smiles>

$17.3 \pm 3.5 \mu \mathrm{M}$<smiles>COc1ccccc1CSCC1Nc2ccc(C(=O)N3CCN(c4ccccc4C)CC3)cc2NC1=O</smiles>

$22.0 \pm 1.0 \mu \mathrm{M}$<smiles>Cc1ccc(N(C)S(=O)(=O)c2ccc3[nH]cc(C(=O)N4CCN(c5ccccc5)CC4)c(=O)c3c2)cc1C</smiles>

$36.1 \pm 3.0 \mu \mathrm{M}$<smiles>CCC(=O)Nc1nc(C)c(-c2csc(Nc3ccc(N(C)C)cc3)n2)s1</smiles>

$41.6 \pm 0.5 \mu \mathrm{M}$<smiles>COC(=O)c1ccc(-c2ccc(/C=C3\C(=O)N(c4ccc(S(N)(=O)=O)cc4)N=C3C(F)(F)F)o2)cc1</smiles><smiles>[R6][R6]#[R6]O[M]</smiles><smiles>CO[14C](=O)[O-]</smiles>

ManNAc $6900 \mu \mathrm{M}$

Figure 2.

Structures of compounds identified in the high throughput screen that function as potent inhibitors in both protein-carbohydrate and cell-based assays. All compounds were derived from commercially available ChemDiv or Chembridge libraries. $\mathrm{IC}_{50}$ values for the fluorescence assay employing Man-Fl-BSA are shown. 
(a)

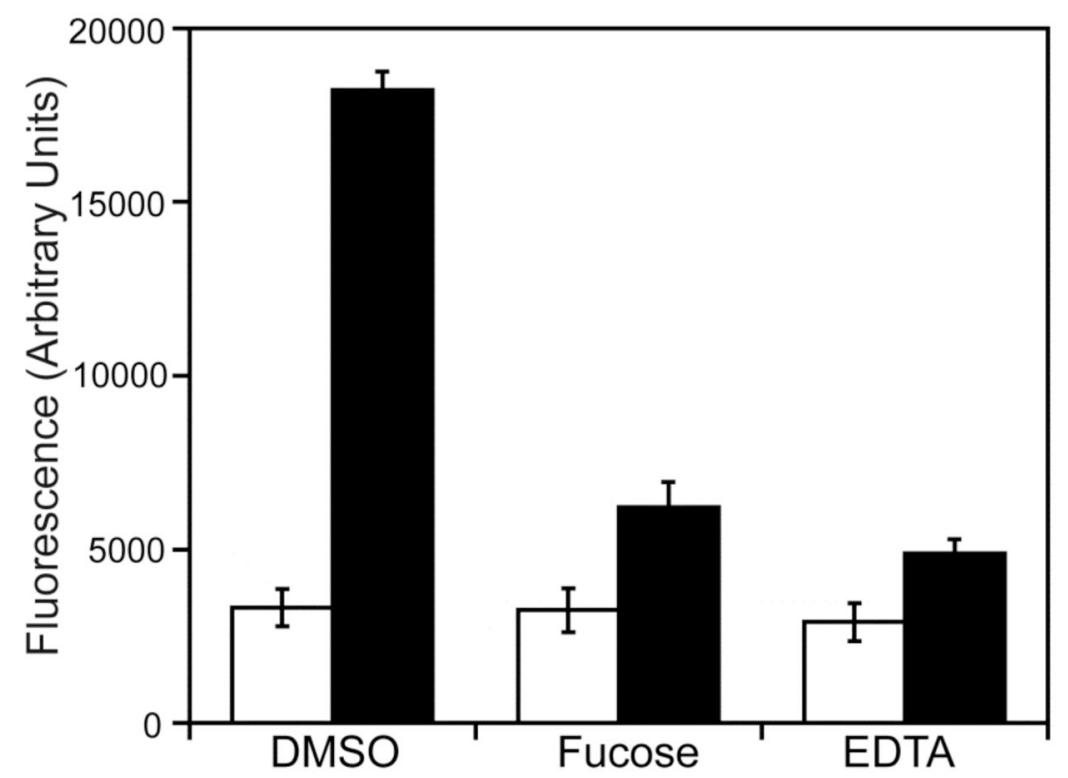

(b)

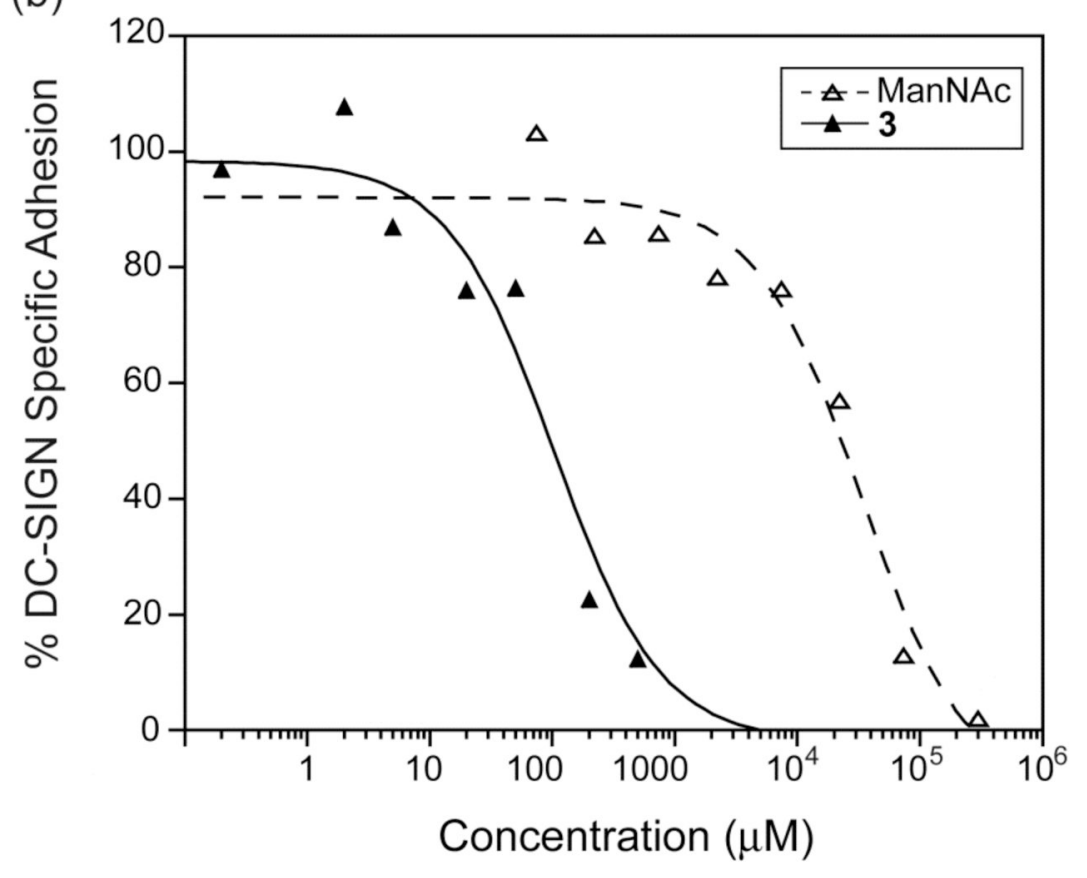

Figure 3.

Data from the cell adhesion assay. (a) DC-SIGN (black)-transfected 293FT cells bind tightly to mannan-coated plates while mock-transfected cells (white) do not. DC-SIGN-specific binding can be abrogated with EDTA $(10 \mathrm{mM})$ or L-fucose $(25 \mathrm{mM})$. (b) Compound $\mathbf{3}$ (solid lines) potently inhibits DC-SIGN-specific cell adhesion to mannan coated plates at approximately 100-fold lower concentrations than does ManNAc (dashed lines). 


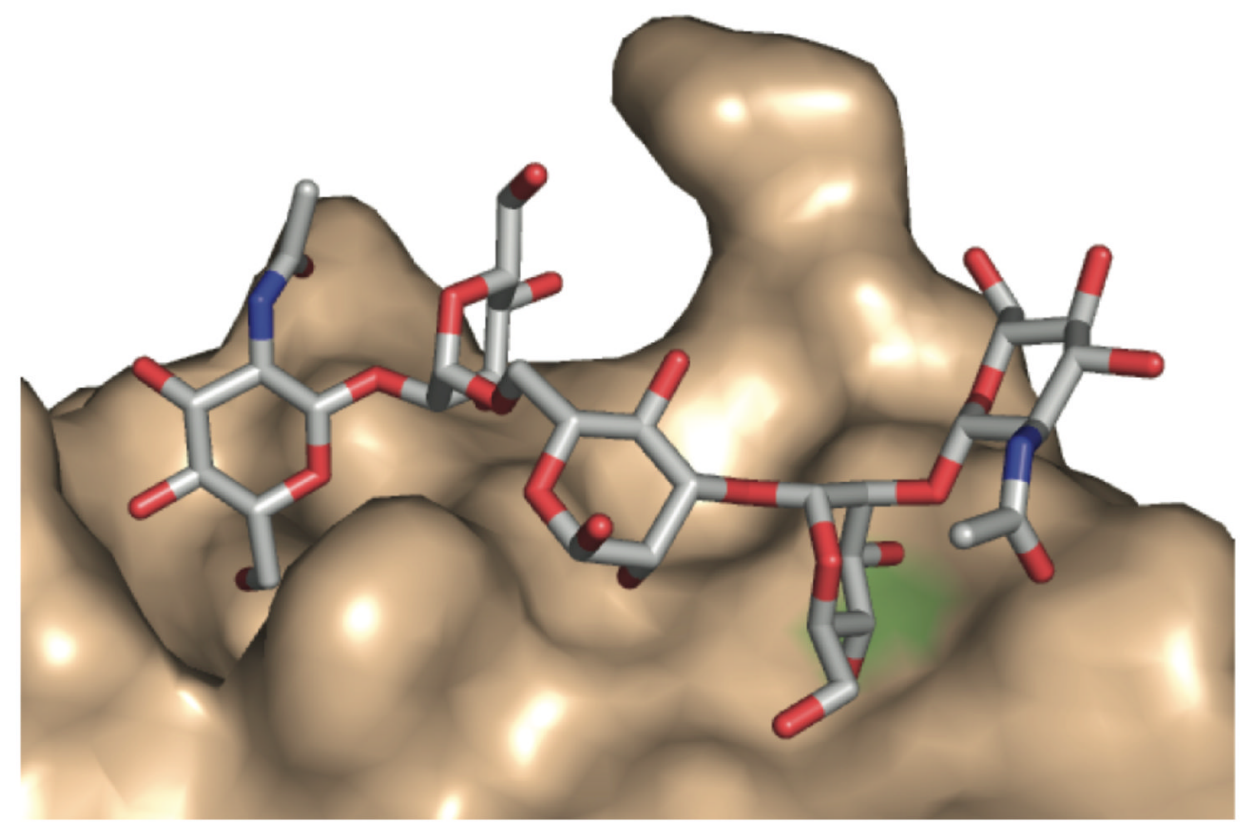

Figure 4.

Model of $\mathrm{Ca}^{2+}$-dependent binding of GlcNAc $2 \mathrm{Man}_{3}$ to DC-SIGN that illustrates the carbohydrate binding site. Hydroxyl groups from the oligosaccharide bind the $\mathrm{Ca}^{2+}$ ion (green). This structure was determined by x-ray crystallography by the Weis and Drickamer groups (reference 58).The figure was generated using Pymol with the PDB entry 1K9I. 
Table 1

$\mathrm{IC}_{50}$ values for identified inhibitors from DC-SIGN-dependent cell adhesion assay

\begin{tabular}{ccc}
\hline Compound & $\mathbf{I C}_{\mathbf{5 0}}(\boldsymbol{\mu M})$ \\
\hline $\mathbf{1}$ & $178 \pm 81$ \\
$\mathbf{2}$ & $227 \pm 100$ & $92 \pm 29$ \\
$\mathbf{3}$ & 0 & $37 \pm 13$ \\
$\mathbf{4}$ & $60 \pm 14$ & $60 \pm 46$ \\
$\mathbf{5}$ & $\mathbf{6}$ & 28,000 \\
\hline
\end{tabular}

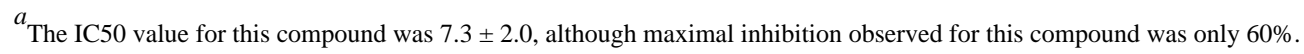

